\title{
Effects of Ginkgo biloba leaf extract on local renin-angiotensin system through TLR4/NF-кB pathway in cardiac myocyte
}

\author{
HUA JIANG and PENG QU
}

Department of Cardiology, The Second Affiliated Hospital of Dalian Medical University, Dalian, Liaoning 116027, P.R. China

Received June 21, 2017; Accepted October 6, 2017

DOI: $10.3892 /$ etm.2017.5313

\begin{abstract}
The present study investigated the effects of Ginkgo biloba leaf extract (GBE50) on lipopolysaccharide (LPS) induced Toll-like receptor 4 (TLR4)/nuclear factor- $\kappa \mathrm{B}$ $(\mathrm{NF}-\kappa \mathrm{B})$ signaling pathway and its effects on angiotensinogen (ATG) and $\mathrm{AT}_{1 \mathrm{a}}$ receptor, so as to explore the mechanism of GBE50 in prevention and treatment of left ventricular remodeling. In vitro cultured neonatal rat ventricular myocytes (NRVMs) were divided into 4 groups including i) control group: DMEM medium; ii) LPS group: iii) LPS + GBE50 group; iv) LPS + caffeic acid phenethyl ester (CAPE, specific inhibitor of $N F-\kappa B$ ) group. Nuclear translocation of $\mathrm{NF}-\kappa \mathrm{B}$ p65 was detected by immunocytochemical method after intervention for $24 \mathrm{~h}$. Expression of TLR4, ATG, $\mathrm{AT}_{1 \mathrm{a}}$ receptors and $\beta$-myosin heavy chain $(\beta-\mathrm{MHC})$ mRNA were detected by reverse transcription-polymerase chain reaction (RT-PCR). Protein content of cardiomyocytes was measured by Coomassie Brilliant Blue method. Under LPS stimulation, expression level of TLR4 mRNA in NRVMs was significantly increased $(\mathrm{P}<0.01)$, nuclear translocation of $\mathrm{NF}-\kappa \mathrm{B}$ p 65 was increased, expression levels of ATG, $\mathrm{AT}_{1 \mathrm{a}}$ receptor and $\beta$-MHC mRNA and the protein content in cells were also increased significantly $(\mathrm{P}<0.01)$. GBE50 and CAPE significantly inhibited nuclear translocation of $\mathrm{NF}-\kappa \mathrm{B}$ p65. GBE50 and CAPE treatments also reduced the increased mRNA levels of TLR4, $\mathrm{ATG}, \mathrm{AT}_{1 \mathrm{a}}$ receptor and $\beta-\mathrm{MHC}$ and protein content in cell caused by LPS stimulation. We concluded that, GBE50 can inhibit the activation of local renin-angiotensin system by inhibiting the activation of TLR4/NF- $\kappa \mathrm{B}$ and TLR4/NF- $\kappa \mathrm{B}$, signaling pathway inhibition may be one of the mechanisms of the role of Ginkgo biloba leaf extract in preventing myocardial remodeling.
\end{abstract}

Correspondence to: Dr Peng Qu, Department of Cardiology, The Second Affiliated Hospital of Dalian Medical University, 467 Zhongshan Road, Shahekkou, Dalian, Liaoning 116027, P.R. China

E-mail: qqn8dd@163.com; qupeng777@aliyun.com

Key words: Toll-like receptor 4, nuclear factor-кB, neonatal rat ventricular myocytes, lipopolysaccharide, Ginkgo biloba leaf extract

\section{Introduction}

In 1999, researchers observed that Toll-like receptor 4 (TLR4) was highly expressed in myocardial cells. In normal mice and human myocardium, expression of TLR4 in cardiomyocyte is mainly diffused in cytoplasm. However, expression of TLR4 was upregulated in the myocardium of rats after infarction which is far away from the lesion of ischemic injury and in myocardium of patients with dilated cardiomyopathy. TLR4 staining showed very strong signal at the junction of two or more than two cells (1). It has been shown that lipopolysacchride (LPS) and AngII can synergistically increase intracellular $\mathrm{Ca}^{2+}$ levels at rest, reduce the transient increase of $\mathrm{Ca}^{2+}$ level and damage the function of mitochondria (2). Later on, more studies have shown that TLR4/nuclear factor- $\kappa \mathrm{B}(\mathrm{NF}-\kappa \mathrm{B})$, a signal transduction pathway closely related to immune, inflammatory and oxidative stress, is closely related to the local renin-angiotensin system (RAS). TLR4/NF- $\kappa \mathrm{B}$ is involved in inflammatory response of myocardial injury and physiological processes of myocardial remodeling, and intervention of TLR4/NF- $\kappa \mathrm{B}$ signal can attenuate myocarditis and myocardial damage (3-5). Ginkgo biloba extract (GBE) is a traditional Chinese medicine that plays an important role in anti-myocardial injury, and function of GBE is related to its role in scavenging oxygen free radical and suppressing immune response (6-8). However, the involvement of TLR4/NF- $\mathrm{B}$ signaling pathway in myocardial remodeling prevention through GBE is still unknown. In this study, TLR4/NF- $\kappa \mathrm{B}$ signaling pathway in rat ventricular myocytes was activated in vitro using LPS, which is a TLR4 specific agonist $(9,10)$. The effects of Ginkgo biloba leaf extract (GBE50) on TLR4/NF- $\kappa \mathrm{B}$ signal and local RAS were observed, and the mechanism of GBE50 in the prevention and treatment of myocardial remodeling was also explored.

\section{Materials and methods}

Experimental animals and major reagents. Healthy new born Sprague-Dawley rats (6-24 hour old) without restriction on sex were provided by Experimental Animal Center of Dalian Medical University. GBE: Gingko biloba (GBE50) containing $44.1 \%$ of Ginkgo biloba total flavonoids and $6.4 \%$ of ginkgolides was provided by SPH Xingling Science and Technology Pharmaceutical Co., Ltd. (Dalian, China). LPS (055:B5), caffeic acid phenethyl ester (CAPE), a specific 
inhibitor of NF-kB, type II collagenase, trypsin, and 5-bromo deoxyuridine (Brdu) were from Sigma (St. Louis, MO, USA). TRIzol and Dulbecco's modified Eagle's medium (DMEM) medium were from Gibco (New York, NY, USA). Reverse transcription kit was bought from Takara (Dalian, China). Rabbit anti-rat striated muscle specific sarcomeric $\alpha$-actin polyclonal antibody (dilution, 1:200; cat. no. PA5-21396) and SP immunohistochemistry kit which included biotinylated secondary antibody, hydrogen peroxide, serum blocker and horseradish peroxidase labeled streptavidin were from Zymed (San Diego, CA, USA). Rabbit anti-rat NF-кB p65 polyclonal antibody (dilution, 1:100; cat. no. SC8008) was from Santa Cruz Biotechnology, Inc. (Dallas, TX, USA). Coomassie Brilliant Blue was from Beijing Zhongshan Golden Bridge Biotechnology Co., Ltd. (Beijing, China).

Primary culture of cardiomyocyte and grouping. Ventricles were collected from Sprague-Dawley rats aged 6-24 h under sterile conditions and were cut into pieces. $0.1 \%$ trypsin and $0.1 \%$ type II collagenase were added to digest the cells to make single cell suspension. Cardiac fibroblasts and epithelial cells were removed using differential attachment technique. Striated muscle specific sagcomeric $\alpha$-actin monoclonal antibody was used to identify cardiomyocytes by SABC immunohistochemical staining. In the first $48 \mathrm{~h}$ of culture, $0.1 \mathrm{mmol} / \mathrm{l} \mathrm{Brdu}$ was added to inhibit the proliferation of non-cardiomyocytes. DMEM culture medium without serum was used after culture for $96 \mathrm{~h}$ when cells reached sub-cell-fusion state. After culture for another $24 \mathrm{~h}$, cells were divided into the following groups: i) control group: DMEM medium without any intervention factors; ii) LPS group: DMEM medium containing $1 \mu \mathrm{g} / \mathrm{ml}$ LPS; iii) LPS + GBE50 group: GBE50 was added first to the final concentration of $80 \mu \mathrm{g} / \mathrm{ml}$, then LPS was added to the final concentration of $1 \mu \mathrm{g} / \mathrm{ml} 30 \mathrm{~min}$ later; iv) LPS + CAPE group: CAPE was added first to the final concentration of $20 \mu \mathrm{g} / \mathrm{ml}$, 30 min later, LPS was added to the final concentration of $1 \mu \mathrm{g} / \mathrm{ml}$. After intervention for $24 \mathrm{~h}$, cells were collected.

Immunocytochemical analysis of the activation of $N F-\kappa B$. Density of neonatal rat ventricular myocytes (NRVMs) was adjusted to $1 \times 10^{6} / \mathrm{ml}$ and inoculated on cell culture plate with coverglass in each well. After treatment for $24 \mathrm{~h}$, coverglasses were collected and washed with PBS. Fixation was performed with $1 \%$ paraformaldehyde $(\mathrm{pH} 7.0)$ at room temperature for $30 \mathrm{~min}$, followed by washing with $0.1 \%$ Triton X-100 (pH 7.0) at room temperature for $5 \mathrm{~min}$. Rabbit anti-mouse NF- $\mathrm{KB}$ p65 antibody $(1: 100)$ was added, followed by incubation at $37^{\circ} \mathrm{C}$ for $60 \mathrm{~min}$. Biotin-avidin reaction system was used. After color development with DAB and hematoxylin re-staining, slides were sealed. Determination of immunocytochemical results were as follows: because NF- $\mathrm{KB}$ is in cytoplasm under normal condition, after activation, it will enter into nucleus, nuclearpositivity was used as the criteria for the determination of the activation of NF- $\mathrm{kB}$. Under light microscope (200-fold; Olympus, Tokyo, Japan), 5 visual fields were randomly selected. The activation of NF- $\mathrm{kB}$ was assessed by calculating the percentage of positive cells.

Detection of the expression of TLR4, AT $T_{1 a}$ receptor, angiotensinogen (ATG) and $\beta$-myosin heavy chain $(\beta-M H C)$ mRNA in cardiomyocytes. Primers were synthesized by Takara. Total RNA was extracted using TRIzol reagent according to the instruction. RNA sample with $\mathrm{OD}_{260} / \mathrm{OD}_{280}=1.6-1.8$ were used for reverse transcription. Reverse transcription conditions: $30^{\circ} \mathrm{C}$ for $10 \mathrm{~min}$, $50^{\circ} \mathrm{C}$ for $30 \mathrm{~min}$ and $99^{\circ} \mathrm{C} 5 \mathrm{~min}$. RT-PCR was performed to detect the expression of TLR4, $\mathrm{AT}_{1 \mathrm{a}}$ receptor, ATG and $\beta$-MHC mRNA. TLR4 primer sense, 5'-CGCTTTCAGCTTTGCCTT CATTAC-3' and antisense, 5'-AGCTACTTCCTTGTGCCCTGT GAG-3', length of amplified fragment was $555 \mathrm{bp}$; ATG primer sense, 5'-TTCAGGCCAAGACCTCCC-3' and antisense, 5'-CCAGCCGGGAGGTGCAGT-3', length of amplified fragment was $308 \mathrm{bp}$; $\mathrm{AT}_{1 \mathrm{a}}$ primer sense, 5'-GCACACTGGCAATG TAATGC-3' and antisense, 5'-GTTGAACAGAACAAGTG ACC-3', length of amplified fragment was $385 \mathrm{bp}$; $\beta$-MHC primer sense, 5'-GTGGACGTTTATTGACTTCGG-3' and antisense, 5'-TTCTTTGCTTTGCCTTTGC-3', length of amplified fragment was $399 \mathrm{bp}$; endogenous control $\beta$-actin primer sense, 5'-AACCCTAAGGCCAACCGTGAAAAG-3' and antisense, 5'-TCATGAGGTAGTCTGTCAT-3', length of amplified fragment was $241 \mathrm{bp}$. PCR reaction conditions for TLR4, $94^{\circ} \mathrm{C}$ for $2 \mathrm{~min}$, followed by 30 cycles of $94^{\circ} \mathrm{C}$ for $30 \mathrm{sec}, 60^{\circ} \mathrm{C}$ for $60 \mathrm{sec}$ and $72^{\circ} \mathrm{C}$ for $1.5 \mathrm{~min}$, and $72^{\circ} \mathrm{C}$ for $10 \mathrm{~min}$; PCR reaction conditions for ATG, $94^{\circ} \mathrm{C}$ for $2 \mathrm{~min}$, followed by 30 cycles of $94^{\circ} \mathrm{C}$ for $30 \mathrm{sec}, 63^{\circ} \mathrm{C}$ for $60 \mathrm{sec}$ and $72^{\circ} \mathrm{C}$ for $1.5 \mathrm{~min}$, and $72^{\circ} \mathrm{C}$ for $10 \mathrm{~min}$; PCR reaction conditions for $\mathrm{AT}_{1 \mathrm{a}}$ receptor, $94^{\circ} \mathrm{C}$ for $2 \mathrm{~min}$, followed by 30 cycles of $94^{\circ} \mathrm{C}$ for $30 \mathrm{sec}, 58^{\circ} \mathrm{C}$ for $45 \mathrm{sec}$ and $72^{\circ} \mathrm{C}$ for $1.5 \mathrm{~min}$, and $72^{\circ} \mathrm{C}$ for $10 \mathrm{~min}$; PCR reaction conditions for $\beta$-MHC, $94^{\circ} \mathrm{C}$ for $2 \mathrm{~min}$, followed by 35 cycles of $94^{\circ} \mathrm{C}$ for $30 \mathrm{sec}, 55^{\circ} \mathrm{C}$ for $45 \mathrm{sec}$ and $72^{\circ} \mathrm{C}$ for $1 \mathrm{~min}$, and $72^{\circ} \mathrm{C}$ for $7 \mathrm{~min}$. PCR products were subjected to $1.5 \%$ agarose gel electrophoresis. A gel imaging system was used to take the images. The ratio of the absorbance of the target gene band to the absorbance of the $\beta$-actin band was taken as the relative expression level of target mRNA.

Determination of protein content in cardiomyocytes. Cells were digested with $0.125 \%$ trypsin, and $0.1 \%$ SDS $(0.1 \mathrm{ml})$ was added to lysis cells, followed by centrifugation at $2,000 \mathrm{x}$ g for 5 min to collect supernatant. Total protein content of cardiomyocytes was measured by Coomassie Brilliant Blue method.

Statistical analysis. Data were processed using SPSS 11.5 statistical software (version X; IBM, Armonk, NY, USA). Each sample was measured three times in parallel, and the data were expressed as mean \pm standard deviation (mean $\pm \mathrm{SD}$ ). Comparisons among multiple samples were performed by variance analysis. Comparisons between two samples were performed by $\mathrm{Q}$ test. $\mathrm{P}<0.05$ was considered to be statistically significant.

\section{Results}

Culture and identification of NRVMS. After fibroblasts were removed by differential attachment technique, cells were cultured for $24 \mathrm{~h}$. Cardiomyocytes were long rod-, polygonal or spindle-shaped with concentric or radial growth. After culture for $48 \mathrm{~h}$, synchronized pulsation (12-80 bpm) was observed in cardiomyocytes. Immunocytochemical identification of striated muscle specific sarcomeric $\alpha$-actin showed that the purity of cardiomyocytes was $>95 \%$. 


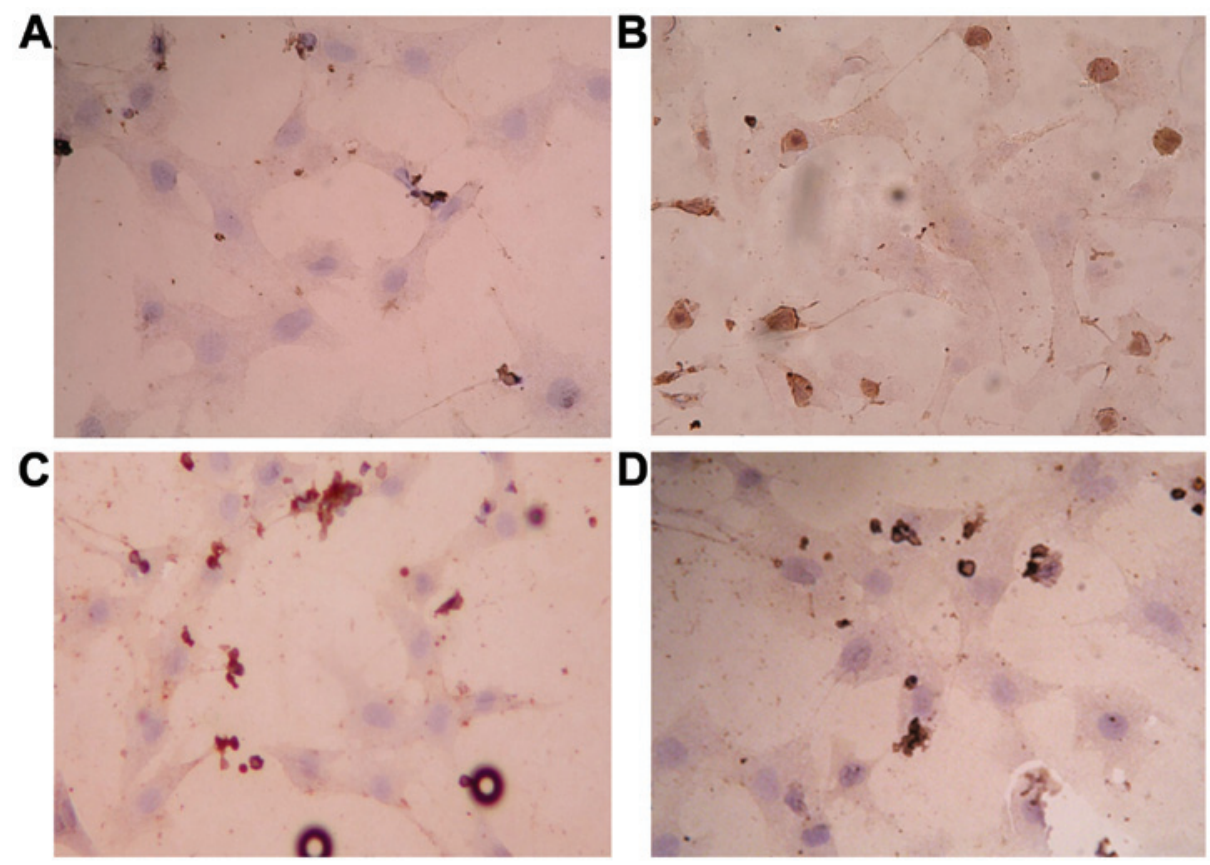

Figure 1. Nuclear translocation of nuclear factor- $\mathrm{kB}(\mathrm{NF}-\mathrm{\kappa B})$ detected by immunocytochemical method. (A) Control group, almost no signal in nucleus; (B) lipopolysaccharide (LPS) group, nuclear membrane and nuclear were stained; (C) LPS + Ginkgo biloba leaf extract (GBE50), almost no signal in nucleus; (D) LPS + caffeic acid phenethyl ester (CAPE), almost no signal in nucleus (magnification, $\mathrm{x} 200$ ).
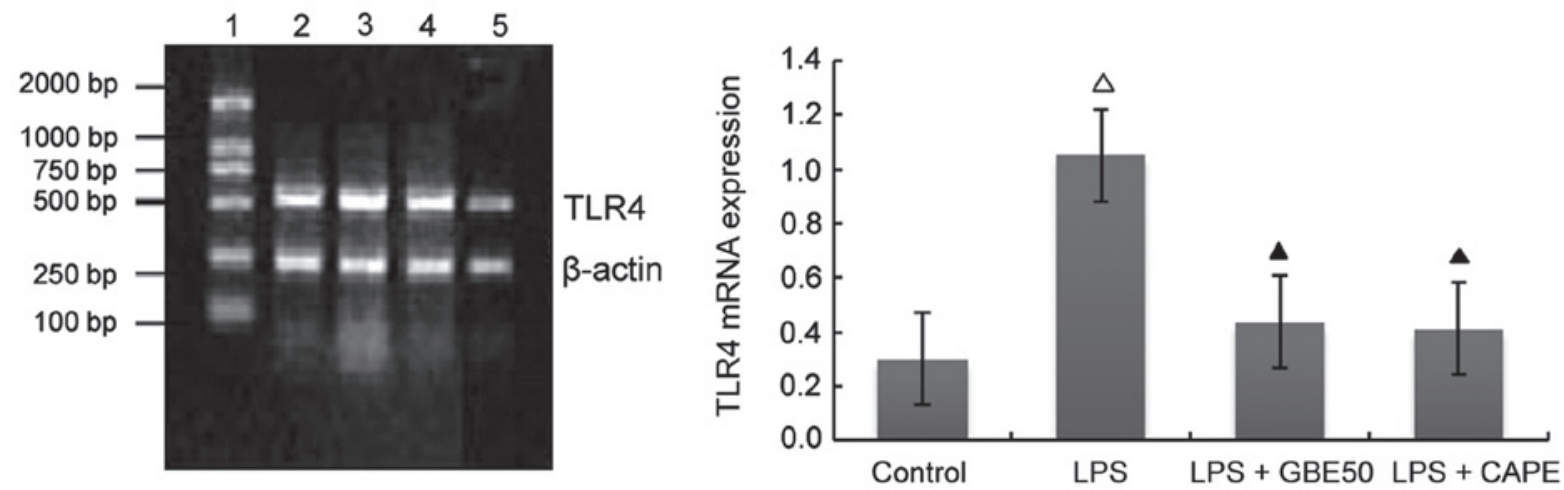

Figure 2. RT-PCR amplification of TLR4. Lipopolysaccharide (LPS) upregulated expression level of TLR4 mRNA in neonatal rat ventricular myocytes (NRVMs), whereas Ginkgo biloba leaf extract (GBE50) and caffeic acid phenethyl ester (CAPE) reduced LPS-induced increase in expression level of TLR4. 1, DNA marker; 2, control group; 3, LPS group; 4, LPS + GBE50 group; 5, LPS + CAPE group. ${ }^{\wedge} \mathrm{P}<0.01$ compared with control group; ${ }^{\wedge} \mathrm{P}<0.01$ compared with the LPS group.

Effects of GBE50 and NF- $\kappa B$ inhibitor CAPE on activation of NF- $\kappa B$ induced by LPS in NRVMs. Results of immunocytochemical analysis showed that NF- $\kappa$ B was activated $24 \mathrm{~h}$ after LPS $(1 \mu \mathrm{g} / \mathrm{ml})$ stimulation, and nuclear staining was significantly increased $(\mathrm{P}<0.01)$. After treatment with GBE50 $(80 \mu \mathrm{g} / \mathrm{ml})$ and CAPE $(20 \mu \mathrm{g} / \mathrm{ml})$, almost no nuclear staining was observed $(\mathrm{P}<0.01)$ (Fig. 1).

Effects of GBE50 and NF- $\kappa B$ inhibitor CAPE on TLR4 mRNA expression induced by LPS in NRVMs. Compared with control

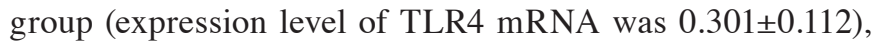
expression level of TLR4 mRNA in NRVMs were significantly increased at $24 \mathrm{~h}$ after LPS $(1 \mu \mathrm{g} / \mathrm{ml})$ stimulation (expression level of TLR4 mRNA was $1.052 \pm 0.227, \mathrm{P}<0.01)$; compared with LPS group, GBE50 $(80 \mu \mathrm{g} / \mathrm{ml})$ and CAPE $(20 \mu \mathrm{g} / \mathrm{ml})$ significantly reduced the expression of TLR4 mRNA in
NRVMs induced by LPS (expression levels of TLR4 mRNA were $0.436 \pm 0.145$ and $0.411 \pm 0.123$, respectively, $\mathrm{P}<0.01$ ). Compared with LPS + GBE50 group, expression level of TLR4 mRNA was slightly reduced in LPS + CAPE group, but the difference was not significant (Fig. 2).

Effects of GBE50 and NF- $\kappa B$ inhibitor CAPE on LPS-induced expression of ATG mRNA in NRVMs. Compared with control group (expression level of ATG mRNA was 0.652 \pm 0.227 ), expression level of ATG mRNA was significantly increased in NRVMs at $24 \mathrm{~h}$ after LPS $(1 \mu \mathrm{g} / \mathrm{ml})$ stimulation (expression level of ATG mRNA was $0.652 \pm 0.227, \mathrm{P}<0.01)$. GBE50 $(80 \mu \mathrm{g} / \mathrm{ml})$ and CAPE $(20 \mu \mathrm{g} / \mathrm{ml})$ could inhibit the increased expression level of ATG mRNA induced by LPS (expression levels of ATG mRNA were 0.171 \pm 0.102 and $0.141 \pm 0.097$, respectively, $\mathrm{P}<0.01)$. No significant differences 

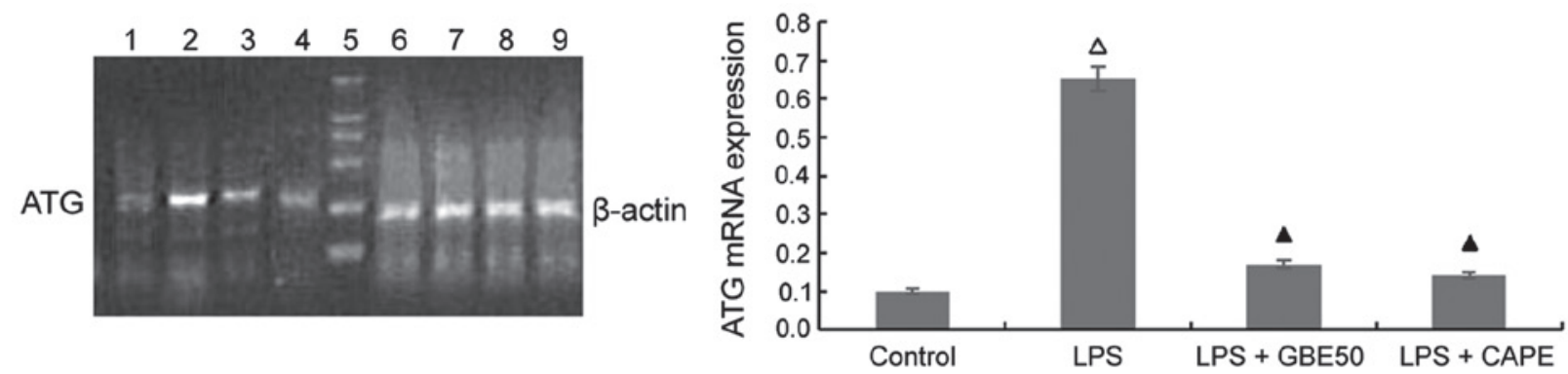

Figure 3. RT-PCR amplification of ATG. Lipopolysaccharide (LPS) upregulated expression level of ATG mRNA in neonatal rat ventricular myocytes (NRVMs), whereas Ginkgo biloba leaf extract (GBE50) and caffeic acid phenethyl ester (CAPE) reduced LPS-induced increase in expression level of ATG. 5, DNA marker, bands from bottom to top are 100, 250, 500, 750, 1,000 and 2,000 bp; 1-4, angiotensinogen (ATG); 6-9, $\beta$-actin; 1,6, control group; 2,7, LPS group; 3,8, LPS + GBE50 group; 4,9, LPS + CAPE group. ${ }^{\triangle} \mathrm{P}<0.01$ compared with control group; ${ }^{\wedge} \mathrm{P}>0.05$ compared with contol group.
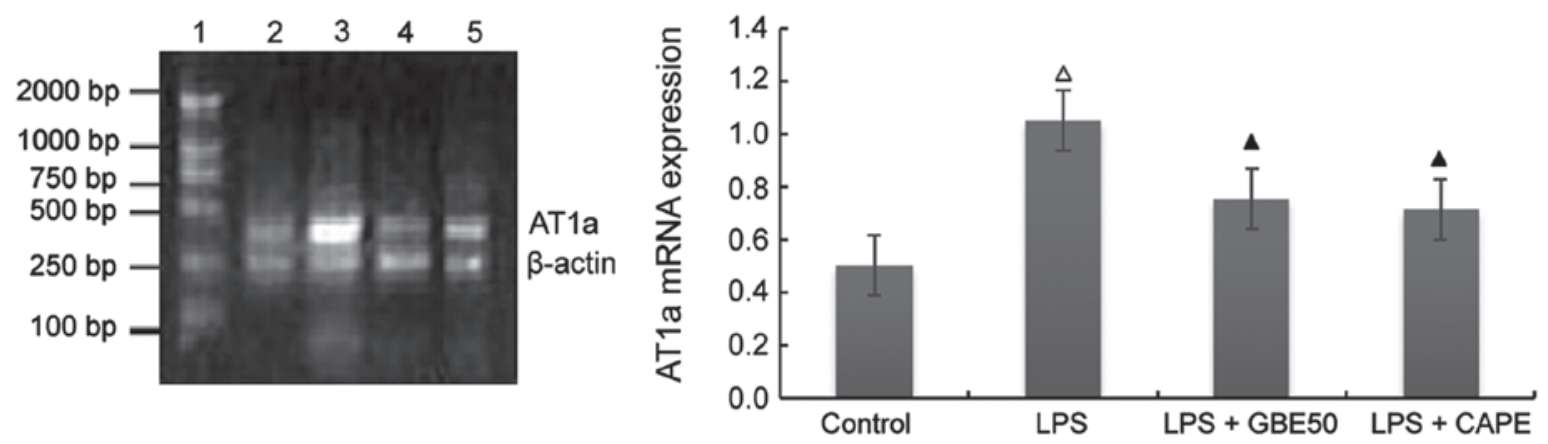

Figure 4. RT-PCR amplification of $\mathrm{AT}_{1 \mathrm{a}}$ receptor. Lipopolysaccharide (LPS) upregulated expression level of $\mathrm{AT}_{1 \mathrm{a}}$ receptor mRNA in neonatal rat ventricular myocytes (NRVMs), whereas Ginkgo biloba leaf extract (GBE50) and caffeic acid phenethyl ester (CAPE) reduced LPS-induced increase in expression level of $\mathrm{AT}_{1 \mathrm{a}}$ receptor mRNA. 1, DNA marker; 2 , control group; 3 , LPS group; 4, LPS + GBE50 group; 5, LPS + CAPE group. ${ }^{\triangle} \mathrm{P}<0.01$ compared with control group; ${ }^{\wedge} \mathrm{P}<0.01$ compared with the LPS group.
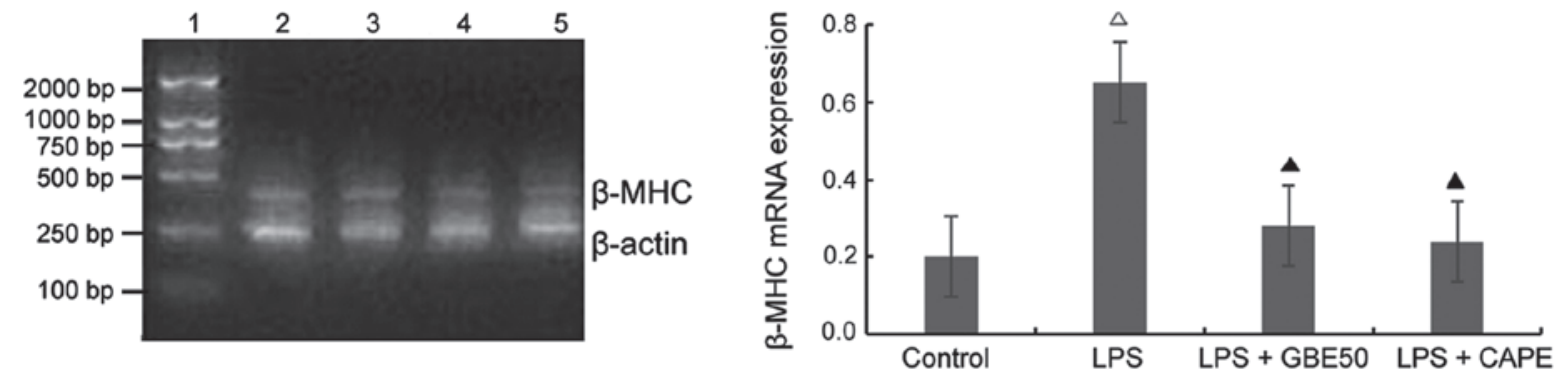

Figure 5. RT-PCR amplification of $\beta$-myosin heavy chain ( $\beta$-MHC). Lipopolysaccharide (LPS) upregulated expression level of $\beta$-MHC mRNA in neonatal rat ventricular myocytes (NRVMs), whereas Ginkgo biloba leaf extract (GBE50) and caffeic acid phenethyl ester (CAPE) reduced LPS-induced increase in expression level of $\beta$-MHC mRNA. 1, DNA marker; 2 , control group; 3, LPS group; 4 , LPS + GBE50 group; 5 , LPS + CAPE group. ${ }^{\triangle} \mathrm{P}<0.01$ compared with control group; ${ }^{\wedge} \mathrm{P}<0.01$ compared with the LPS group.

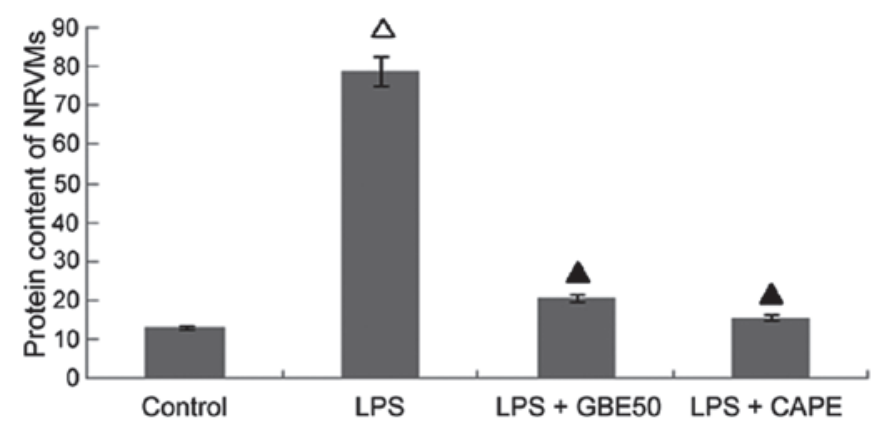

Figure 6. Protein content of each group. ${ }^{\triangle} \mathrm{P}<0.01$ compared with control group; ${ }^{\wedge} \mathrm{P}<0.01$ compared with the lipopolysaccharide (LPS) group. in the expression level of ATG mRNA were found between LPS + GBE50 group, LPS + CAPE group and control group. Compared with LPS + GBE50 group, expression level of ATG mRNA was slightly reduced in LPS + CAPE group, but the difference was not significant (Fig. 3).

Effect of GBE50 and NF- $\kappa B$ inhibitor CAPE on expression of $A T_{\text {Ia }}$ receptor $m R N A$ induced by LPS in NRVMs. Compared with control group (expression level of $\mathrm{AT}_{1 \mathrm{a}}$ receptor mRNA was $0.501 \pm 0.112$ ), expression level of $\mathrm{AT}_{1 \mathrm{a}}$ receptor mRNA in NRVMs were significantly increased at $24 \mathrm{~h}$ after LPS $(1 \mu \mathrm{g} / \mathrm{ml})$ stimulation (expression level of TLR4 mRNA was $1.05 \pm 0.227$, $\mathrm{P}<0.01)$; compared with LPS group, GBE50 $(80 \mu \mathrm{g} / \mathrm{ml})$ and 
CAPE $(20 \mu \mathrm{g} / \mathrm{ml})$ significantly reduced the expression of $\mathrm{AT}_{1 \mathrm{a}}$ mRNA in NRVMs induced by LPS (expression levels of $\mathrm{AT}_{1 \mathrm{a}}$ receptor mRNA were $0.751 \pm 0.257$ and $0.711 \pm 0.223$, respectively, $\mathrm{P}<0.01$ ). No significant difference in the expression level of $\mathrm{AT}_{1 \mathrm{a}}$ receptor mRNA was found between LPS + GBE50 group, LPS + CAPE group and control group. Compared with LPS + GBE50 group, expression level of $\mathrm{AT}_{1 \mathrm{a}}$ receptor mRNA was slightly reduced in LPS + CAPE group, but the difference was not significant (Fig. 4).

Effect of GBE50 and NF- $\kappa B$ inhibitor CAPE on expression of $\beta$-MHC mRNA induced by LPS in NRVMs. Compared with control group (expression level of $\beta$-MHC mRNA was $0.201 \pm 0.098)$, expression level of $\beta$-MHC mRNA in NRVMs were significantly increased at $24 \mathrm{~h}$ after LPS $(1 \mu \mathrm{g} / \mathrm{ml})$ stimulation (expression level of $\beta$-MHC mRNA was $0.653 \pm 0.228$, $\mathrm{P}<0.01)$; compared with LPS group, GBE50 $(80 \mu \mathrm{g} / \mathrm{ml})$ and CAPE $(20 \mu \mathrm{g} / \mathrm{ml})$ significantly reduced the expression of $\beta$-MHC mRNA in NRVMs induced by LPS (expression levels of $\beta$-MHC mRNA were $0.201 \pm 0.098$ and $0.191 \pm 0.089$, respectively, $\mathrm{P}<0.01)$. No significant difference in the expression level of $\beta$-MHC mRNA was found between LPS + GBE50 group, LPS + CAPE group and control group. Compared with LPS + GBE50 group, expression level of $\beta$-MHC mRNA was slightly reduced in LPS + CAPE group, but the difference was not significant (Fig. 5).

Effects of GBE50 and NF- $\kappa B$ inhibitor CAPE on increased protein content in NRVMs cells induced by LPS. Compared with control group (protein content was $13.18 \pm 2.51 \mathrm{mg} / \mathrm{l}$ ), protein content in NRVMs were significantly increased at $24 \mathrm{~h}$ after LPS $(1 \mu \mathrm{g} / \mathrm{ml})$ stimulation (protein content was $78.81 \pm 8.51 \mathrm{mg} / 1, \mathrm{P}<0.01)$; compared with LPS group, GBE50 $(80 \mu \mathrm{g} / \mathrm{ml})$ and CAPE $(20 \mu \mathrm{g} / \mathrm{ml})$ significantly reduced the increased protein content in NRVMs induced by LPS (protein contents were $20.80 \pm 3.42$ and $15.78 \pm 3.02 \mathrm{mg} / \mathrm{l}$, respectively, $\mathrm{P}<0.01)$. No significant difference in protein content was found between LPS + GBE50 group, LPS + CAPE group and control group. Compared with LPS + GBE50 group, protein content was slightly reduced in LPS + CAPE group, but the difference was not significant (Fig. 6).

\section{Discussion}

In 1997, Medzhitov et al (11) found the first human Toll protein-TLR4, confirming the presence of TLR4/NF- $\kappa B$ signaling pathway in human body. TLR4/NF- $\kappa \mathrm{B}$ is the primary pathway that mediates LPS signaling, and LPS from Escherichia coli can specifically activate TLR4 without affecting other members of Toll-like receptor families $(9,10)$. Our results showed that TLR4 was expressed in NRVMs, and LPS increased the expression level of TLR4, ATG and $\mathrm{AT}_{1 \mathrm{a}}$ receptor, and also increased the indexes of cardiomyocyte hypertrophy - protein content in cardiomyocytes and expression level of $\beta$-MHC expression, suggesting that TLR4/NF- $\mathrm{KB}$ signaling pathway may be involved in the occurrence and development of cardiomyocyte hypertrophy by activating local renin-angiotensin system. NF- $\mathrm{kB}$ is a group of multidirectional nuclear transcriptional regulators. Under normal conditions, p50 and p65, which are two subunits of NF- $\mathrm{kB}$, can form heterodimers in cytoplasm, in the inactive form of

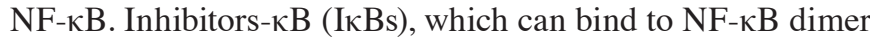
to mask the nuclear localization sequence of NF- $\mathrm{KB}$, controls the activation of NF- $\kappa B$. Phosphorylation and activation of inhibitor- $\kappa \mathrm{B}$ kinase (IKK) can be induced by a variety of stimulatory factors, and phosphorylated I $\kappa B$ s will replease and activate NF- $\mathrm{kB}$, then NF- $\mathrm{kB}$ will translocate from cytoplasm to nucleus to bind the target genes, which in turn regulate the expression of a series of target genes related to the pathophysiological processes of cardiovascular disease and promote protein synthesis in cardiomyocytes. The target genes include cytokines, angiotensinogen, AT1 receptor and embryonic genes such as $\beta$-MHC (12). In vivo and in vitro experiments have shown that NF- $\mathrm{\kappa B}$ is the essential nuclear transcriptional regulator for the development of cardiac hypertrophy $(13,14)$. In this study, $24 \mathrm{~h}$ after LPS stimulation, NF- $\mathrm{kB}$ p65 was activated, while NF- $\kappa B$ inhibitor CAPE inhibited the activation of NF- $\mathrm{kB}$ p65 and reduced the expression levels of angiotensinogen, $\mathrm{AT}_{1 \mathrm{a}}$ receptor, $\beta$-MHC and increased protein content in cardiomyocytes. Therefore, TLR4/NF- $\kappa \mathrm{B}$ is involved in the LPS-induced changes in cardiomyocytes, and NF- $\kappa B$ may play a key role.

GBE50 is the concentrated and purified active ingredient of Ginkgo biloba. GBE50 contains $44.1 \%$ of Ginkgo biloba total flavonoids, $26.4 \%$ of flavonoid glycosides and $6.4 \%$ of ginkgolides. Ginkgolides can effectively inhibit the activation of platelet and flavonoids can remove oxygen free radicals to achieve antioxidant effect. It is reported that GBE can remove oxygen free radicals and reduce the expression levels of p53 and Bcl-2, so GBE is widely used in the treatment of cardiovascular disease (6-8). Myocardial ischemia and reperfusion experiments found that GBE can increase antioxidant activity in plasma, which in turn protects the heart (15). In animal models of doxorubicin-induced chronic cardiotoxicity, Naidu et al (16) showed that GBE could reduce the adipokine-induced increase in myocardial lipid peroxidation and restored the antioxidant activity of superoxide dismutase and reduced glutathione, which in turn protects the heart from adriamycin toxicity and reduces mortality. GBE50 inhibited the activation of TLR4/NF- $\mathrm{kB}$ and local RAS in NRVMs induced by LPS, and also reduced the expression of $\beta$-MHC and decreased the protein content and reversed cardiac hypertrophy. TLR4/NF- $\mathrm{KB}$ and RAS are also closely related to myocardial remodeling, suggesting that GBE50 may have an important role in the prevention and treatment of myocardial remodeling. Results of this study suggest that GBE50 and NF-кB inhibitor CAPE have similar effects, and they both can significantly inhibit the activation of NF- $\mathrm{kB}$. Studies have shown that reactive oxygen species are involved in the activation of NF- $\mathrm{KB}$ induced by LPS, and various antioxidants can inhibit NF- $\kappa B$ activation $(1,12)$. So the inhibitory effects of GBE50 on NF-кB activation may be related to the function of GBE50 in scavenging oxygen free radicals.

In this study, LPS upregulated expression level of TLR4 in NRVMs, while GBE50 reduced the increased expression level of TLR4. Compared with LPS + GBE50 group, expression level of TLR4 mRNA was slightly reduced in LPS + CAPE group, but the difference was not significant. In vitro studies performed by Frantz et al (1) suggested that NF- $\kappa$ B activation can not only mediate downstream signal transduction of TLR4, but also is necessary for maintaining TLR4 expression. 
Results of this study showed that expression level of TLR4 was increased after the activation of $\mathrm{NF}-\kappa \mathrm{B}$, while expression level of TLR4 was decreased with the inhibited activation of $N F-\kappa B$, suggesting that the regulatory role of GBE50 in TLR4 expression may also be associated with the inhibition of NF- $\kappa \mathrm{B}$ activation. Through decreasing the expression level of TLR4, GBE50 indirectly inhibited the activation of NF- $\mathrm{B}$, which in turn reduced TLR4/NF- $\kappa \mathrm{B}$ signal, so as to inhibit the activation of RAS, reduce expression level of $\beta$-MHC and increase protein content in cardiomyocytes with activated TLR4/NF-кB pathway.

In conclusion, GBE50 can inhibit the activation of $N F-\kappa B$ and expression of TLR4 induced by LPS, which in turn attenuate TLR4/NF- $\kappa \mathrm{B}$ signaling pathway and reduce the increased expression levels of angiotensinogen and $\mathrm{AT}_{1 \mathrm{a}}$ receptors. TLR4/NF- $\kappa \mathrm{B}$ signaling pathway intervention may be one of the mechanisms of GBE in preventing myocardial remodeling.

\section{Acknowledgements}

We are grateful for the support of the National Natural Science Foundation of China (grant no. 30371568).

\section{References}

1. Frantz S, Kobzik L, Kim YD, Fukazawa R, Medzhitov R, Lee RT and Kelly RA: Toll4 (TLR4) expression in cardiac myocytes in normal and failing myocardium. J Clin Invest 104: 271-280, 1999

2. Yasuda S and Lew WY: Angiotensin II exacerbates lipopolysaccharide-induced contractile depression in rabbit cardiac myocytes. Am J Physiol 276: H1442-H1449, 1999.

3. Li HL, Suzuki J, Bayna E, Zhang FM, Dalle Molle E, Clark A, Engler RL and Lew WY: Lipopolysaccharide induces apoptosis in adult rat ventricular myocytes via cardiac AT(1) receptors. Am J Physiol Heart Circ Physiol 283: H461-H467, 2002.

4. Li HB, Li X, Huo CJ, Su Q, Guo J, Yuan ZY, Zhu GQ, Shi XL, Liu JJ and Kang YM: TLR4/MyD88/NF- $\kappa B$ signaling and PPAR- $\gamma$ within the paraventricular nucleus are involved in the effects of telmisartan in hypertension. Toxicol Appl Pharmacol 305: 93-102, 2016.
5. Dange RB, Agarwal D, Masson GS, Vila J, Wilson B, Nair A and Francis J: Central blockade of TLR4 improves cardiac function and attenuates myocardial inflammation in angiotensin II-induced hypertension. Cardiovasc Res 103: 17-27, 2014.

6. Liu AH, Bao YM, Wang XY and Zhang ZX: Cardio-protection by Ginkgo biloba extract 50 in rats with acute myocardial infarction is related to $\mathrm{Na}^{+}-\mathrm{Ca}^{2+}$ exchanger. Am J Chin Med 41: 789-800, 2013

7. Lu S, Guo X and Zhao P: Effect of Ginkgo biloba extract 50 on immunity and antioxidant enzyme activities in ischemia reperfusion rats. Molecules 16: 9194-9206, 2011.

8. Liu TJ, Yeh YC, Ting CT, Lee WL, Wang LC, Lee HW, Wang KY, Lai HC and Lai HC: Ginkgo biloba extract 761 reduces doxorubicin-induced apoptotic damage in rat hearts and neonatal cardiomyocytes. Cardiovasc Res 80: 227-235, 2008.

9. Takada H, Yokoyama S and Yang S: Enhancement of endotoxin activity by muramyldipeptide. J Endotoxin Res 8: 337-342, 2002.

10. Wang J,Zhang Y, Guo LL, Wu GJ and Liu RH: Salvianolic acid B inhibits the TLR4-NFאB-TNF $\alpha$ pathway and attenuates neonatal rat cardiomyocyte injury induced by lipopolysaccharide. Chin J Integr Med 17: 775-779, 2011.

11. Medzhitov R, Preston-Hurlburt P and Janeway CA Jr: A human homologue of the Drosophila Toll protein signals activation of adaptive immunity. Nature 388: 394-397, 1997.

12. Jones WK, Brown M, Ren X, He S and McGuinness M: NF-kappaB as an integrator of diverse signaling pathways: The heart of myocardial signaling? Cardiovasc Toxicol 3: 229-254, 2003.

13. Purcell NH, Tang G, Yu C, Mercurio F, DiDonato JA and Lin A: Activation of NF-kappa B is required for hypertrophic growth of primary rat neonatal ventricular cardiomyocytes. Proc Natl Acad Sci USA 98: 6668-6673, 2001.

14. Shi Y, Pan H,Zhang HZ, Zhao XY, Jin J and Wang HY: Lipoxin A4 mitigates experimental autoimmune myocarditis by regulating inflammatory response, NF- $\mathrm{KB}$ and PI3K/Akt signaling pathway in mice. Eur Rev Med Pharmacol Sci 21: 1850-1859, 2017.

15. Carini M, Aldini G, Rossoni G, Morazzoni P and Facino RM: Complexation of Ginkgo biloba extract with phosphatidylcholine improves cardioprotective activity and increases the plasma antioxidant capacity in the rat. Planta Med 67: 326-330, 2001

16. Naidu MU, Kumar KV, Mohan IK, Sundaram C and Singh S: Protective effect of Gingko biloba extract against doxorubicininduced cardiotoxicity in mice. Indian J Exp Biol 40: 894-900, 2002. 